\title{
Internalisasi Nilai Hukum Islam dalam Rancangan KUHP di Indonesia (Studi terhadap Tindak pidana perzinahan dalam KUHP dan RKUHP )
}

\author{
$\operatorname{Lisma}^{1} *$ \\ ${ }^{1}$ Institut Agama Islam Negeri Surakarta, Jl. Pandawa, Dusun IV, Pucangan, Kec. Kartasura, \\ Kabupaten Sukoharjo, Jawa Tengah-57168, Indonesia. \\ * Korespondensi Penulis. E-mail: lislisma10@gmail.com
}

\begin{abstract}
Abstrak
Hukum pidana yang berlaku saat ini sejatinya sudah usang dan seharusnya diperbaharui untuk mengikuti perkembangan zaman, kendati demikian formulasi hukum pidana warisan kolonial hanya mementingkan aspek individual padahal hukum seyogianya memperhatikan aspek individual dan sosial. Hukum islam sebagai salah satu sistem hukum yang ada di dunia juga diakui dan berlaku di Indonesia bukan merupakan hal yang baru, berbagai aspek yang diatur dalam hukum islam sebenarnya mampu menjawab berbagai keresahan dalam praktik berhukum selama ini yang masih menggunakan hukum pidana warisan belanda. eksistensi hukum islam di Indonesia bukan hanya disebabkan oleh faktor sejarah melainkan masyarakat yang telah mendiami wilayah Nusantara telah memperaktikan nilai-nilai hukum islam sejak zaman kerajaan, sehingga masyarakat Indonesia yang beradab menolak segala bentuk perbuatan yang menyimpang dari norma agama, moral, sosial dan hukum. Namum praktik hukum islam pada masa penjajahan tidak dapat diberlakukan karena kaidah politik hukum menghendaki rezim politik mempengaruhi jenis hukum yang diberlakukan. Sejak berlakuknya hukum pidana kolonial hingga sekarang banyak menimbulkan persoalan-persoalan dalam masyarakat, seperti kumpul kebo, penistaan agama, perjudian dan minuman keras. Internalisasi hukum islam dalam pembaharuan hukum pidana sejalan dengan hukum kebiasaan dan hukum adat yang tidak memperbolehkan setiap perbuatan yang melanggar hukum kebiasaan dan hukum adat dalam suatu masyarakat seperti dalam budaya bugis siri' yang tidak memperbolehkan membawa lari anak gadis orang begitupun di hukum adat kajang yang tidak memperbolehkan perempuan dan laki-laki berboncengan atau berdua-duan, di Aceh bahkan telah membuat aturan setingkat daerah tentang larangan seorang wanita dan laki-laki berdua-duan. Internalisasi nilai tersebut mengharuskan setiap formulasi hukum yang ingin dimasukan dalam RKUHP menggali saripati hukum islam yang berasal dari al-Qur'an, Sunnah dan Qiyas. Penelitian ini menggunakan metode deskriftif analitis dengan pendekatan yuridis normative yang mengkaji peraturan perundang-undangan yang berkaitan dengan persoalan tersebut dan dipadukan bahan-bahan hukum kepustakaan yang dapat menjelaskan fungsi hukum islam dalam memecahkan persolan hukum di Indonesia.
\end{abstract}

Kata Kunci: hukum pidana nasional, hukum islam, internalisasi, RKUHP

\section{Internalization value islamic of law in the draft penal code Indonesia (Study of Adultery Crimes in the Criminal Code and Draft Penal Code)}

\begin{abstract}
The current criminal law is in fact absoluete and should be renewed to keep pace with the times, not the formulation yet of the criminal law of the colonial inheritance is concerned only with the individual aspect whereas the law should pay attention to individual and social aspect. Islamic law as one of the existing legal system in the world is also recognized and applicable in Indonesia is not a new thing, the various aspects regulated in Islamic law is actually able to answer the various unrest in the practice of punishment so far that still use the dutch criminal law inheritance. The existence of islamic law in Indonesia is not only due to historical factors but the people who have inhabited the archipelago has been devoted to the values of Islamic law since the time of the kingdom, so that civilized Indonesian society reject all forms of acts deviating from religious, moral, social and legal norms. However, the practice of Islamic law in the colonial period can not be enforced because the political rule of law requires the political regime to influence the type of law imposed. Since the passage of colonial criminal
\end{abstract}


EKSPOSE: Jurnal Penelitian Hukum dan Pendidikan, 18 (1), June 2019 - 722

Lisma

law until now many cause problems in society, such as congregation kebo, blasphemy, gambling and liquor. The internalization of Islamic law in the renewal of the penal law is in line with customary law and customary law which does not allow any act that violates customary law and customary law in a society as in the siri 's bugis culture which does not permit the carrying of child girls as in customary kajang law allowing women and men to rally or to be together, even in Aceh have even made regionallevel rules about the prohibition of a woman and a man on a budget. Internalization of these values requires that every formulation of law to be included in the draft penal code unearth the essence of Islamic law derived from the Qur'an, Sunnah and Qiyas. This study uses descriptive analytical method with normative juridical approach that examines the legislation relating to the issue and incorporated library literary materials that can explain the function of Islamic law in solving legal issues in Indonesia.

Keywords: national criminal law, islamic law, internalisation, draft penal code 


\section{PENDAHULUAN}

Hukum pidana yang sedang diberlakukan di negara Indonesia saat ini telah mengalami fase yang kritis karena kondisi masyarakat yang terus mengalami perkembangan sehingga hukum pidana yang merupakan warisan kolonial tidak mampu lagi membendungnya. Ditengah pergolakan hukum warisan kolonial tersebut dengan masyarakat telah berlangsung proses pembaharuan hukum pidana nasional sebagai jawaban dari keresahan atas persoalan tersebut. KUHP sebagai produk hukum belanda terus mengalami upaya-upaya pembaharuan. substansi dari KUHP saat ini bersifat individualistik dan tidak sesuai dengan nilai-nilai yang hidup dalam masyarakat Indonesia. Berbagai penyakit dalam masyarakat terus bermunculan karena legitimasi hukum yang lemah dan hanya memihak pada aspek pribadi.

Pembaharuan hukum pidana yang termaktub dalam KUHP mengharuskan memperbaharui hukum pidana materil, hukum pidana formil dan hukum pelaksanaan pidana. pembaharuan dalam hukum pidana tidak hanya memperhatikan aspek individual tetapi harus memperhatikan aspek sosial, alam dan tradisi Indonesia yang bermartabat serta berbudi luhur.

Kehadiran RKUHP sebagai upaya untuk memperbaharui hukum pidana lama warisan belanda yang sudah cukup lama bercokol atau malang-melintang dalam memobilisasikan dunia peradilan di Indonesia, hukum pidana masa kini cukup mengkoyak-koyak dan menghadirkan kondisi dishumanistik terhadap para pencari keadilan. Berlakunya KUHP berarti secara yuridis normatif telah menamatkan riwayat dan wilayah kerja HIR (hukum acara pidana lama). HIR ini pernah menanam etos kerja yuridis dengan model pemisahan kelas dalam menegakan hukum dan memarginalkan konsep persamaan hukum (equality before the law) serta memutar-balikan atau dapat dijadikan alat mendramatisir antara kebenaran dan kesalahan. Posisi pihak yang benar dan seharusnya berhak atas keadilan justru memperoleh tempat mengenaskan dibandingkan yang bersalah dan melakukan pelanggaran hukum. ${ }^{1}$

Pembahruan hukum pidana nasional juga harus memperhatikan nilai-nilai yang terdapat dalam lapisan masyarakat Indonesia. Meskipun Indonesia bukan merupakan negara agama namun sejarah Indonesia tidak lepas dari kontribusi pemikiran ulama yang beragama islam. Perjuangan kemerdekaan berasal dari latar belakang yang berbeda baik perbedaan suku, agama dan budaya. keberadaan agama islam telah ada sebelum kemerdekaan yang dijadikan pedoman bagi pemeluknya, hal tersebut berdampak pada kondisi masyarakat Indonesia terutama dari golongan ulama yang menerapkan aturanaturan islam yang bersumber dari al-qur'an dan hadist.

Hukum islam merupakan salah satu sistem hukum yang diberlakukan di Indonesia bukan hanya karena faktor kesejarahan melainkan masyrakat yang beragama islam mutlak menaati hukum-hukum yang berada di dalam al'qur'an dan sunnah. Agama islam yang rahmatan lil alamin seyogianya dapat menjadi prinsip dasar dari hukum islam yang dapat ditransformasikan nilainya dalam pembaharuan hukum pidana yang tidak hanya meperhatikan aspek individu tetapi meperhatikan aspek sosial dan alam. Namun persoalan yang sulit untuk dipecahkan lahirnya dikotomi antara hukum agama dengan hukum nasional sehingga salah satu hukum termarjinalkan padahal nilai hukum islam dapat ditransformasikan ke dalam hukum pidana nasional dengan menjadikan al-qur'an dan hadist sebagai salah satu sumber pembentukan hukum nasional.

Urgensi nilai-nilai Hukum Islam dalam peraturan perundang-undangan dimaksudkan untuk mengetahui dan sekaligus memahami manfaat pengimplemantasian atau konseptualisasi dari perwujudan nilai-nilai syariat islam sebagai bagian dari nilai-nilai agama dalam peraturan perundangundangan di Indonesia dalam mewujudkan hukum nasional. ${ }^{2}$ Hukum islam memang telah diakomidir dalam beberapa hukum nasional seperti hukum perdata namun keberadaan hukum tersebut juga mengalami diskursus yang panjang karena persoalan Indonesia bukan negara agama, begitupun hukum pidana yang terakomodir dalam hukum pidana nasional masih setengah. Melalui pergolakan eksistensi hukum islam tersebut maka penulis menemukan titik persoalan bahwa penerapan hukum islam dalam hukum Indonesia disebabkan karena penerapan yang bersifat pendikotomian sehingga untuk memaksimalkan penerapan hukum islam perlu mentransformasikan nilai hukum islam ke dalam

${ }^{1}$ Wahid Abdul, Menggugat Idealisme KUHP (Bandung: Tarsito, 1993).

2 Nasaruddin Umar, "Urgensi Transformasi Hukum Islam Dalam Pemajuan Hak Asasi Manusia Di Indonesia," HUNAFA: Jurnal Studia Islamika 12, no. 2 (2015): 231-52. 
rancangan hukum pidana yang akan datang (KUHP) khusunya ke dalam pemidanaan bagi pelaku perzinahan.

Penelitian ini menggunakan kerangka pemikiran hukum profetik, kerangka pikir profetik dimaksudkan dengan melakukan pendudukan ajaran agama (relegious science) dalam perkembangan sejarah pembentukan pemikiran ilmu hukum. Kontribusi agama-agama samawi dalam konstruksi ilmu pengetahuan hukum jelas memperlihatkan buki nyata sebagaimana dikemukakan oleh Plato, Cicero, J. Berman, dan juga Benedict Ruth bahwa (1) agama secara utuh , dan atau sebagai budaya merupakan sistem nilai karena selain dapat berfungsi sebagai pedoman yang mengandung nilai-nilai universal kebenaran dan keadilan (2) agama di sebagian negara-negara muslim telah menjadi agama sebagai ideologi negara yang dimuat dalam konstitusi dan juga terdapat negara-negara muslim yang tidak menjadikan agama sebagai negara agama. (3) bahkan ketika masyrakat belum memiliki negara, agama menjadi pengganti hukum yang dipandang sebagai hukum yang hidup dalam masyarakat jauh lebih efekif daya lakunya karena masyarakat lebih dekat dan familiar denganya ketimbang peraturan hukum undang-undang buatan negara. ${ }^{3}$

Penulis juga menggunakan teori eksistensi dalam hukum islam dan hukum nasional yang dikemukakan oleh Hazarin. Beliau mengemukakan bahwa (1) hukum islam ada dalam hukum nasional yakni berfungsi sebagai bagian integral dari hukum nasional. (2) hukum islam ada yakni berfungsi sebagai penyaring bahan-bahan hukum nasional, (3) hukum islam ada, yakni diakui kemadirianya, kekuatanya, dan diberi status sebagai hukum nasional, dan (4) hukum islam ada, artinya sebagai bahan utama dan unsur utama dalam pembentukan hukum nasional. ${ }^{4}$

\section{METODE}

Penelitian ini menggunakan metode penelitian normatif yang melakukan penelitian terhadap bahan-bahan pustaka yang meliputi (1) penelitian terhadap asas-asas hukum (2) penelitian terhadap sistematika hukum (3) penelitian terhadap taraf sinkronisasi vertikal dan horizontal (4) perbandingan hukum, dan (5) sejarah hukum. Penelitian hukum normatif menggunakan bahan hukum primer dan sekunder, dalam penelitian ini menggunakan bahan hukum primer berupa KUHP, dan AL-qur'an sedangkan bahan hukum sekunder berupa hasil penelitian rancangan undang-undang (RKUHP), hasil karya dari kalangan hukum dan yang terakhir bahan hukum tertier berupa ensiklopedia, kamus dan indeks kumulatif. ${ }^{5}$ Spesifikasi penelitian ini yaitu penelitian deskriptif yang dimaksudkan untuk memberikan data yang seteliti mungkin dengan manusia, keadaan atau gejala-gejala lainya, serta hanya menjelaskan keadaan objek masalahnya tanpa maksud mengambil kesimpulan yang berlaku umum. ${ }^{6}$

\section{PEMBAHASAN}

\section{Tujuan dan Eksisteni Hukum Islam}

Secara global tujuan syara' dalam menetapkan hukum-hukumnya adalah untuk kemaslahatan manusia seluruhnya, namun secara terperinci ada 5 tujuan menetapkan hukum syara' yakni: a) memeliara agama dengan maksud bahwa agama adalah suatu yang harus dimiliki oleh manusia supaya martabatnya dapat terangkat lebih tinggi dari martabat mahluk yang lain. b) memelihara jiwa dengan maksud bahwa islam melarang pembunuhan dan pelaku pembunuhan diancam dengan qisas sehingga diharapkan agar orang sebelum melakukan pembunuhan berfikir 10 kali karena apabila yang dibunuh mati maka pembunuh juga akan mati atau jika orang yang dibunuh itu tidak mati tetapi hanya cedera, maka pelakunya juga akan cedera pula. c) memelihara akal dengan maksud bahwa akal merupakan suatu hal yang penting perananya di dunia ini sehingga dibutuhkan peraturan untuk manusia agar menggunakan akalnya. d) memelihara keturunan dengan maksud bahwa segala bentuk hubungan diluar pernikahan tidak diperbolehkan seperti perzinahan, kumpul kebo dan mengharuskan menikah sesuai ketentuan agama. e) memelihara harta benda dan kehormatan dengan maksud bahwa islam menjaga

3 M Syamsudin, Ilmu Hukum Profetik: Gagasan Awal, Landasan Kefilsafatan, dan Kemungkinan Pengembangannya di Era Postmodern (Pusat Studi Hukum (PSH) FH UII kerja sama dengan FH UII Press, 2013).

${ }^{4}$ Zainuddin Ali, Metode Penelitian Hukum (Jakarta: Sinar Grafika, 2009).

${ }^{5}$ Sri Mamudji and Soerjono Soekanto, Penelitian Hukum Normatif (Jakarta: PT. Raja Grafindo, 2006).

${ }^{6}$ Soekanto Soerjono, Pengantar Penelitian Hukum (Jakarta: Universitas Indonesia, 1986). 
harta benda dan kehormatan melalui aturan muamalat seperti jual beli, sewa menyewa, gadai menggadai dan sebagainya. ${ }^{7}$

Eksistensi hukum islam di Indonesia sangat dipengaruhi oleh situasi politik yang berlaku begitupun dengan kondisi masyarakat Inonesia yang bermayoritaskan islam menjadi landasan untuk diterapkanya hukum islam hanya kepada umat muslim. Hukum islam Indonesia memiliki dua bentuk, yaitu sebagai hukum normatif dan sebagai hukum formal yang dilegislasikan sebagai hukum positif. Pendekatan kultural berhubungan dengan bentuk pertama, sedangkan pendekatan struktural berhubungan dengan bentuk kedua. Legislasi dapat dilakukan dalam dua bentuk: pertama, hukum islam dilegislasikan secara formal untuk umat islam: dan kedua, materi-materi hukum islam diintegrasikan ke dalam hukum nasional tanpa menyebutkan hukum islam secara formal. ${ }^{8}$ Konstitusi Indonesia, pasal 29 ayat 1 UUD 1945 menyatakan bahwa Negara berdasar atas keTuhanan Yang Maha Esa. Hal tersebut mengindikasikan Indonesia sebagai Negara yang memiliki keyakinan terhadap Tuhan Yang Maha Esa dengan keragaman agama. ${ }^{9}$

Penerapan hukum islam di Indonesia sudah dilaksanakan melalui bebrapa aturan hukum seperti diberlakukanya hukum perdata, hukum perkawinan, warisan dan secara struktural Negara Indonesia telah menyediakan fasilitas berupa pengadilan agama berdasarkan UU No 7 tahun 1989 tentang Peradilan Agama. ${ }^{10}$ berlakunya hukum islam sebagai hukum positif di Indonesia membuka lebar pintu masuknya hukum islam di Indonesia yang dimulai secara perlahan dengan mengintegrasikan nilai hukum dan prinsip hukum islam ke dalam hukum pidana di Indonesia yang bisa dijadikan hukum positif dan tidak hanya berlaku bagi umat islam melainkan formulasi tersebut dapat diberlakukan pada seluruh masyarakat Indonesia.

Dalam persfektif hukum Islam, hukum positif Indonesia dapat diklasifikasikan ke dalam tiga kelompok: 1) hukum-hukum yang sejalan dengan hukum Islam seperti hukum keluarga dan sebagian besar hukum perdata: 2) hukum-hukum positif yang tidak bertentangan dengan hukum Islam meskipun tidak sama persis denganya, seperti hukum tentang pembunuhan dan perampokan: 3) hukum-hukum positif yang bertentangan dengan hukum Islam, seperti hukum-hukum tentang hubungan seksual tanpa nikah dan minuman keras yang pelakunya hukumanya hanya dikenakan jika merusak atau mengganggu orang lain. ${ }^{11}$

Bentuk hukum yang ketiga ditolak tidak hanya ditolak oleh umat islam tetapi masyrakat Indonesia yang berbudi luhur dan beradat juga menolak segala bentuk kebebasan dalam berhubungan seperti berzinah dan kumpul kebo. Namun dalam perkembangan hukum pidana di Indonesia tidak mengatur hukuman bagi yang berzinah yang belum bersatatus suami istri atau kumpul kebo yang diatur hanyalah seorang pria atau wanita yang sudah menikah kemudian berselingkuh dan melakukan perzinahan. Padahal dalam hukum Islam telah ditegaskan bahwa perzinahan tidak boleh dilakukan sebagaimana yang tertuang dalam al-Qur'an, yakni:

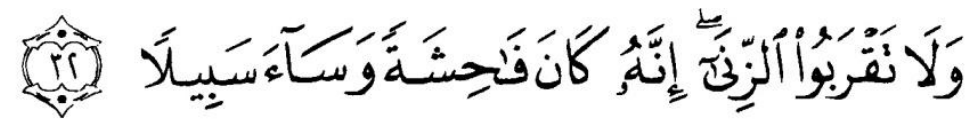

Artinya: Dan janganlah kamu mendekati zina; sesungguhnya zina itu adalah suatu perbuatan yang keji. Dan suatu jalan yang buruk. (al-Isra :17 (32)).

Perzinahan dalam Islam tidak boleh didekati apalagi dilakukan karena perzinahan dapat menimbulkan kerusakan pada diri, keturunan dan lingkungan sehingga segala bentuk hubungan badan tidak boleh dilakukan tanpa pernikahan. Sedangkan dalam KUHP belanda perzinahan di atur dalam aturan sebagai berikut, yakni Pasal 284 (1) Diancam dengan pidana penjara paling lama sembilan bulan. Adapun rinciannya (a) seorang pria yang telah kawin yang melakukan gendak (overaspel), padahal

\footnotetext{
${ }^{7}$ Ismail Muhammad Syah, Filsafat Hukum Islam (Jakarta: Bumi Aksara, 1999).

${ }^{8}$ Bani Syarif Maula, Sosiologi Hukum Islam Di Indonesia: Studi Tentang Realitas Hukum Islam Dalam Konfigurasi Sosial Dan Politik (Aditya Media Publishing, 2010).

${ }^{9}$ Pemerintah Republik Indonesia, “Undang-Undang Dasar Negara Republik Indonesia 1945," Lembaran Negara RI Tahun1959 Nomor 75 (1959).

${ }^{10}$ Pemerintah Republik Indonesia, "UU Nomor 7 Tahun 1989 Tentang Peradilan Agama” (1989).

${ }^{11}$ Maula, Sosiologi Hukum Islam Di Indonesia: Studi Tentang Realitas Hukum Islam Dalam Konfigurasi Sosial Dan Politik.
} 
diketahui bahwa pasal 27 BW berlaku baginya; dan (b) seorang wanita yang telah kawin yang melakukan gendak, padahal diketahui pasal $27 \mathrm{BW}$ berlaku baginya.

Dalam pasal tersebut mengisayaratkan bahwa perbuatan zina yang dilakukan oleh pasangan yang belum menikah dapat dilakukan karena tidak ada larangan baginya dalam KUHP. Sistem hukum Indonesia yang menganut Civil Law System dan menekankan pada asas legalitas formil maka suatu perbuatan hanya dapat dihukum apabila ada aturan yang jelas dan tertulis. Perkembangan Ilmu hukum pidana yang terus berkembang dengan paham pancasila di Indonesia yang hendak mewujudkan negara yang berketuhanan mengharuskan instrumen-instrumen yang ada termasuk instrumen hukum yang berKeTuhanan sehingga segala bentuk penerapan hukum yang dimulai tahap legislasi hingga aplikasi harus disinari dengan pancasila dengan cahaya keTuhanan melalui agama Islam dengan hukum Islam yang dijadikan sebagai salah satu sumber dalam pembentukan sistem hukum pidana nasional dimasa yang akan datang (KUHP).

\section{Relevansi nilai hukum islam dalam Rancangan KUHP}

Relevansi secara asasi dalam bidang asas-asas antara hukum pidana Islam dengan KUHP, yakni asas legalitas, Asas larangan memindahkan kesalahan pada orang lain, dan Asas praduga tidak bersalah. $^{12}$

\section{Asas Legalitas}

Yang dimaksud dengan asas legalitas adalah asas yang menyatakan bahwa tidak ada pelanggaran dan tidak ada hukuman sebelum ada undang-undang yang mengaturya. Asas ini berdasarkan pada alQur'an (QS. 17:15), dihubungkan dengan anak kalimat dalam (QS.6:19), yang berbunyi Al'Qur'an ini diwahyuhkan kepadaku agar (denganya) aku dapat menyampaikan peringatan (dalam bentuk aturan dan ancaman hukuman) kepadamu. Asas legalitas ini telah ada dalam hukum Islam sejak al-Qu'an diturunkan.

\section{Asas Larangan Memindahkan Kesalahan pada Orang Lain}

Asas larangan memindahkan kesalahan pada orang lain, asas ini terdapat di dalam berbagai surat dan ayat Al-Qur'an (QS.6:164), (QS.35:18), (QS.39:7), (QS.53:38), (QS.74:38) misalnya dinyatakan bahwa setiap jiwa terikat pada apa yang dia kerjakan, dan setiap orang tidak memikul dosa atau kesalahan yang diperbuat oleh orang lain (QS. 6:164) Allah menyatakan bahwa setiap pribadi yang melakukan sesuatu kejahatan akan menerima balasan kejahatan yang dilakukanya. Ini berarti bahwa tidak boleh sekali-kali beban seorang dijadikan beban orang lain. hal ini karena tanggung jawab pidana itu individual sifatnya, kesalahan sesorag tidak dapat dipindahkan kepada orang lain.

\section{Asas Praduga Tidak Bersalah}

Asas praduga tidak bersalah, ayat-ayat al'quran yang berkaitan dengan larangan memidanakan kesalahan pada orang lain berkaitan dengan asas praduga tidak bersalah bahwa sesorang yang dituduh melakukan sesuatu kejahatan harus dianggap tidak bersalah sebelum hakim dengan bukti-bukti yang meyakinkan menyatakan dengan tegas kesalahanya.

Aspek pembaharuan dalam hukum pidana yang merupakan hasil dari integrasi dan prinsip nilai hukum islam dapat kita temui dalam perumusan asas legalitas materil, yakni "Dalam menetapkan sumber hukum atau dasar patut dipidananya suatu perbuatan, konsep bertolak dari pendirian bahwa hukum yang utama adalah undang-undang (hukum tertulis). Jadi bertolak dari asas legalitas dalam pengertian yang formal. ${ }^{13}$ Hal ini ditegaskan dalam pasal 1 (1) sedangkan konsep KUHP baru memperluas rumusan secara meteriil dengan menegaskan bahwa ketentuan dalam pasal 1(1) itu tidak mengurangi berlakunya "hukum yang hidup" di dalam masyarakat. dengan demikian disamping sumber hukum tertulis (UU) sebagai kriteria/patokan formal yang utama namun berlakunya hukum yang hidup

\footnotetext{
12 Teguh Prasetyo, Politik Hukum Pidana: Kajian Kebijakan Kriminalisasi Dan Dekriminalisasi (Yogyakarta: Pustaka Pelajar, 2012).

${ }^{13}$ Barda Nawawi Arief, Bunga Rampai Kebijakan Hukum Pidana: Perkembangan Penyusunan KUHP Baru (Jakarta: Kencana Prandamedia Group, 2010).
} 
dalam masyarakat hanya untuk delik-delik yang tidak ada tandinganya atau tidak telah diatur di dalam undang-undang".

Perluasan perumusan asas legalitas ini dalam konsep 1991/1992 dirumuskan dalam pasal 1 ayat (3) yang berbunyi: ketentuan dalam ayat 1 tidak mengurangi berlakunya hukum yang hidup yang menentukan bahwa menurut adat setempat seseorang patut dipidana bilamana perbuatan itu tidak ada persamaan dalam peraturan perundang-undangan. Kehadiran perumusan di atas menunjukan karakteristik asas legalitas menurut pandangan dan pemikiran orang Indonesia yang tidak terlalu formalistis dan terpisah-pisah.

\section{Eksistensi hukum Islam dalam hukum nasional}

Dalam teori eksistesi, hukum Islam telah berlaku sejak Islam masuk di Indoneisa sehingga dapat dipahami bahwa sejak zaman belanda terdapat 3 sistem hukum yang berlaku yakni sistem hukum barat, sistem hukum adat dan sistem hukum Islam seperti yang diilustrasikan pada Gambar 1. Tiga sistem hukum tersebut diterapkan di Indonesia dan masih diberlakukan hingga sekarang karena faktor sejarah telah melegitimasi eksistensinya, selain itu masyarakat Indonesia menerima hukum tersebut karena bermanfaat untuk diterapkan terutama masyrakat indonesia sebahagian besar adalah umat muslim. Pada dasarnya eksistensi hukum islam untuk diterapkan memiliki kekuatan hukum karena dalam konstitusi Negara Indonesia telah mengakui keberadaan hukum islam sebagai bagian dari sistem hukum nasional.

Penyusunan RKUHP telah mengintegrasikan hukum islam di dalamnya karena beberapa prinsip-prinsip hukum islam sebenarnya telah terakomodir di dalam RKUHP salah satunya adalah perluasan asas legalitas menjadi asas legalitas meteriil. Dalam pembaharuan hukum pidana menurut Prof Barda, sistem hukum pidana nasional didasarkan pada nilai keseimbangan yakni: nilai ketuhanan, nilai Kemanusiaan, nilai Kemasyarakatan (nasionalistik, demokratik dan keadilan sosial). Secara nomratif kedudukan hukum islam memberikan implikasi al qur'an dijadikan sebagai salah satu sumber hukum nasional dengan menggali nilai-nilai yang terdapat di dalamnya. Ide keseimbangan tersebut.

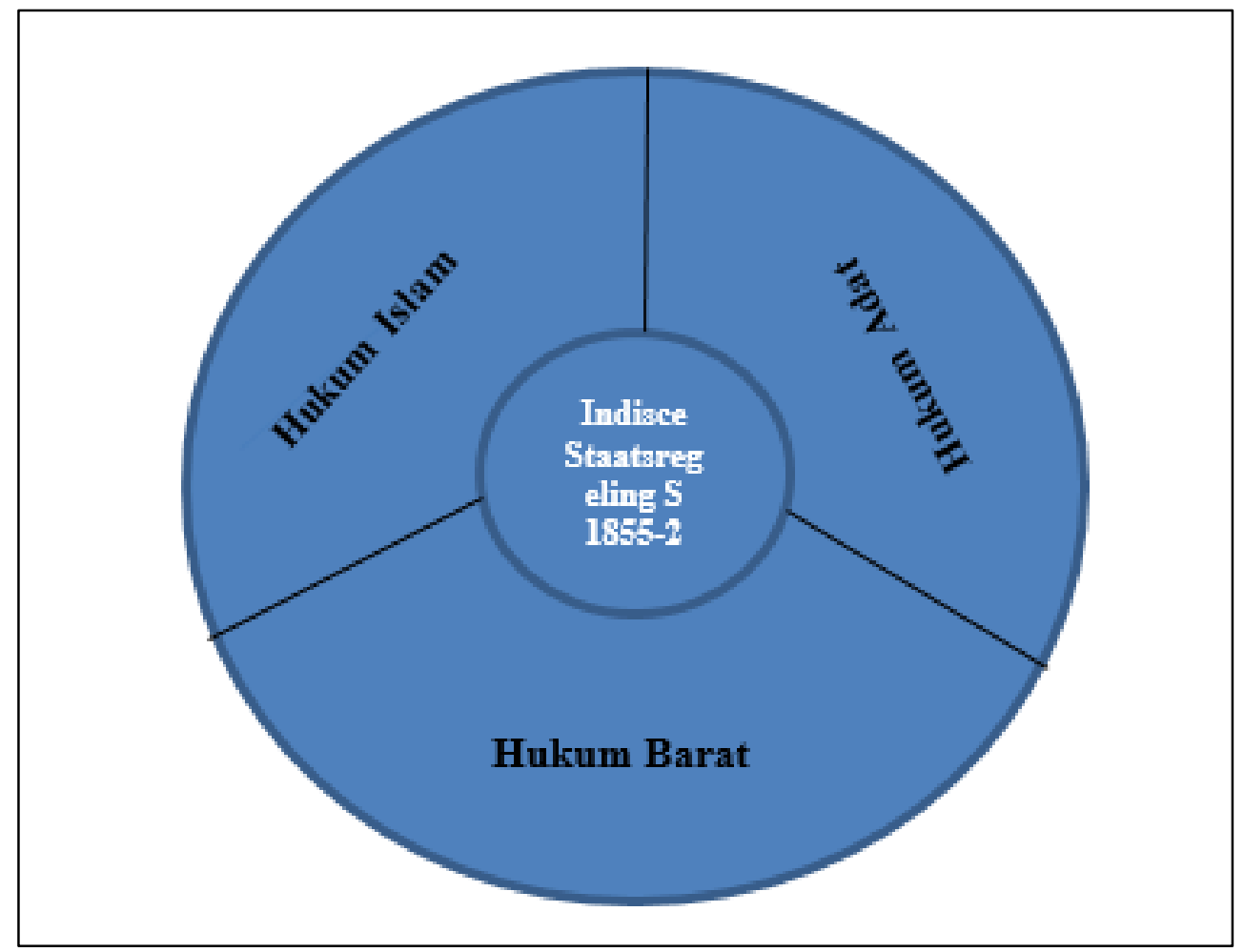

Gambar 1. Tiga Sistem Hukum

Hukum indonesia yang telah mengalami dinamika melahirkan karakteristik hukum nasional yang berlandaskan pancasila seperti yang ditunjukkan pada Gambar 2. Pancasila sebagai sumber hukum materiil dan peraturan perundang-undangan, perjanjian antar negara, yurisprudensi dan kebiasaan sebagai sumber hukum formil. Ada 3 kualitas pancasila sebagai sumber hukum materil yaitu: Pertama, 
pancasila merupakan muatan filosofis bangsa Indonesia. Kedua, muatan pancasila sebagai identitas hukum nasional. Ketiga, Pancasila tidak menentukan perintah, larangan dan sanksi melainkan menentukan asas-asas fundamental bagi pembentukan hukum (meta-juris). ${ }^{14}$

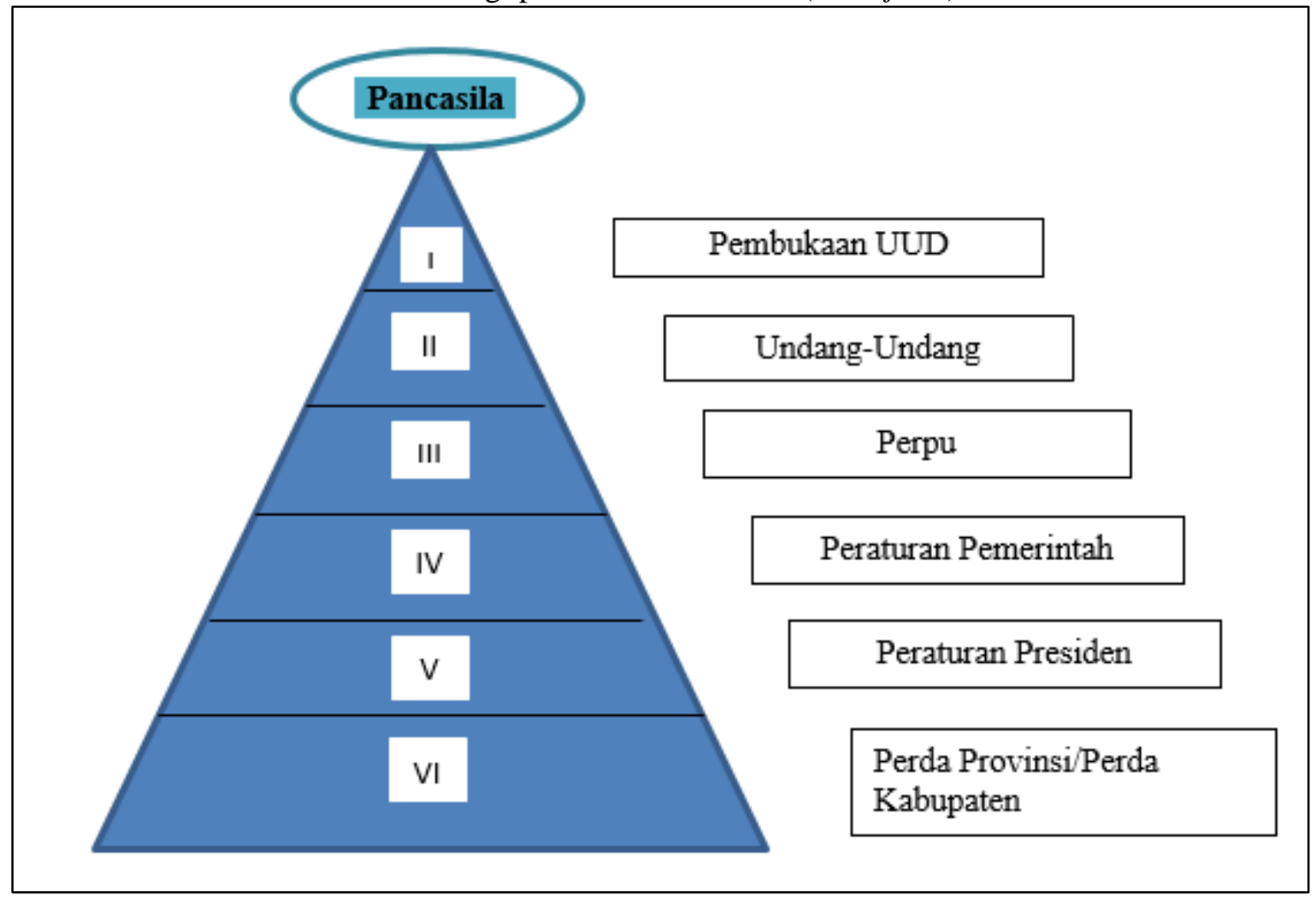

Gambar 2. Dinamika Hukum Indonesia yang Melahirkan Karakteristik Hukum Nasional

Berlandaskan Pancasila

Pancasila sebagai sumber dari segala sumber hukum mengharuskan setiap peraturan yang ada dibawahnya harus tunduk dan apabila terjadi pertentangan maka peraturan tersebut harus dirubah. Dasar negara Indonesia sebagai rule kehidupan masyarakat berbangsa dan negara harus diamalkan dalam sendi-sendi kehidupan baik agama, sosial, politik, hukum dan ekonomi. Pancasila tersebut berasal dari kristalisasi nilai-nilai luhur nenek moyang dahulu yang diterapkan dalam kehidupan sehari-hari. Ajaranajaran luhur tersebut dijaga secara turun temurun sehingga tidak kehilangan nilainya. Ketetapan Pancasila sebagai ideologi negara merupakan kesepaktan bangsa yang mengikat mereka satu sama lain karena sila pada setiap pancasila dapat diterima oleh semua masyarakat hingga masa sekarang.

Beberapa hal fundamental yang harus diperhatikan ialah mendudukan Pancasila sebagai Staatfundamentalnorm yang terbuka ruang untuk didialogkan karena sejarah pembentukan Pancasila sebenarnya sangat kaya dengan nilai-nilai transedental yang dibangun berdasarkan spirit keagamaan. ${ }^{15}$ Dimensi transedental digambarkan dalam hukum profetik dengan konsep humanisasi, liberasi dan transedensi kuntowijoyo yang digunakan dalam membahas ilmu pengetahuan sosial secara umum. Al Qur'an dan Sunnah merupakan dasar utama pengembagan ilmu hukum profetik, profetik yang dipelopori Kuntowijoyo menyerupai konsep integrasi ilmu dan agama oleh Amin Abdullah. Profetik ilmu hukum didasari dengan konsep humanisasi, liberasi dan trannsedensi. Humanisasi merupakan usaha untuk mengangkat martabat manusia melalui jalan Tuhan. Liberasi merupakan ilmu hukum yang

14 Fais Yonas Bo'a, "Pancasila Sebagai Sumber Hukum Dalam Sistem Hukum Nasional," Jurnal Konstitusi 15, no. 1 (2018): 21-49.

${ }^{15}$ Sugeng Wibowo, "Integrasi Epistimologi Hukum Transendental Sebagai Paradigma Hukum Indonesia," Legal Standing: Jurnal Ilmu Hukum 1, no. 1 (2017): 61-88. 
memililiki tanggung jawab profetik untuk membebaskan manusia dari ketidakbaikan. Transedensi merupakan bentuk ilmu hukum yang mengandung unsur-unsur dasar keimanan kepada Allah. ${ }^{16}$

Konsep humanisasi dalam ilmu hukum profetik dapat kita temui dalam rancangan pembaharuan hukum pidana dengan mennggunakan teori keseimbangan dalam pemidanaan dengan memperhatikan masyarakat dan individu yang dikenal dengan pandangan monodualistis dan disebut dengan istilah Daad-dader Strafrecht yaitu hukum pidana yang memperhatikan segi-segi objektif dari perbuatan (Daad) dan juga segi-segi subjektif dari orang/pembuat (dader), bertolak dari prinsip keseimbangan monodualistis itulah maka konsep tetap mempertahankan dua asas yang sangat fundamental dalam hukum pidana, yaitu asas legalitas dan asas kesalahan/culpabilitas. Kedua asas inilah yang masingmasing dapat disebut sebagai "asas kemasyarakatan" dan asas kemanusiaan berbeda dengan KUHP yang sekarang berlaku, yang hanya merumuskan asas legalitas, konesp 1993 merumuskan kedua asas itu secara eksplisit di dalam Pasal 1 (untuk asas legalitas) dan Pasal 35 (untuk asas culpabilitas). ${ }^{17}$

Merelevansikan hukum Indonesia dengan hukum Islam sangat bisa dilakukan dengan upaya mereaktualisasi hukum islam dalam hukum nasional, UU No. 22 Tahun 2009 tentang Lalu Lintas dan Angkutan Jalan Pasal 57 ayat 2 mengatur kewajiban memakai helm bagi pengendara sepeda motor. ${ }^{18}$ Jika kita analisis kewajiban memakai hel bertujuan untuk melindungi keselamatan kepala apabila terjadi kecelakaan lalu lintas. Melindungi keselamatan kepala adalah termasuk bagian dari menjaga keselamatan jiwa/memelihara jiwa (hafidz al-nafs). Dengan demikian, meskipun Undang-undang No. 22 Tahun 2009 tentang Lalu Lintas dan Angkutan jalan tersebut tidak secara eksplisit diberi nama Kompilasi Hukum Islam, namun secara esensial dengan pendekatan reaktualisasi dapat dikatakan sebagai hukum Islam. ${ }^{19}$ Contoh lain ialah keberadaan UU No.35 Tahun 2009 tentang Narkotika dapat dimaknai sebagai pemberantasan kejahatan yang dapat mengancan akal manusia. ${ }^{20}$ Begitupun UU No. 31 Tahun 1999 tentang Pemberantasan Tindak Pidana Korupsi untuk menjaga harta lebih umum harta Negara agar tidak disalahgunakan merupakan spirit agama Islam yang bertujuan untuk memelihara jiwa, akal, harta, keturunan dan agama. ${ }^{21}$

Sejalan dengan penerapan reaktulisasi hukum Islam ke dalam konteks keIndonesiaan, Ibrahim Hosen berpendapat, ulama klasik apabila menemukan realitas yang tidak sejalan dengan al-Qur'an maupun hadits, mereka menolaknya tetap berpegang teguh pada ayat berikut:

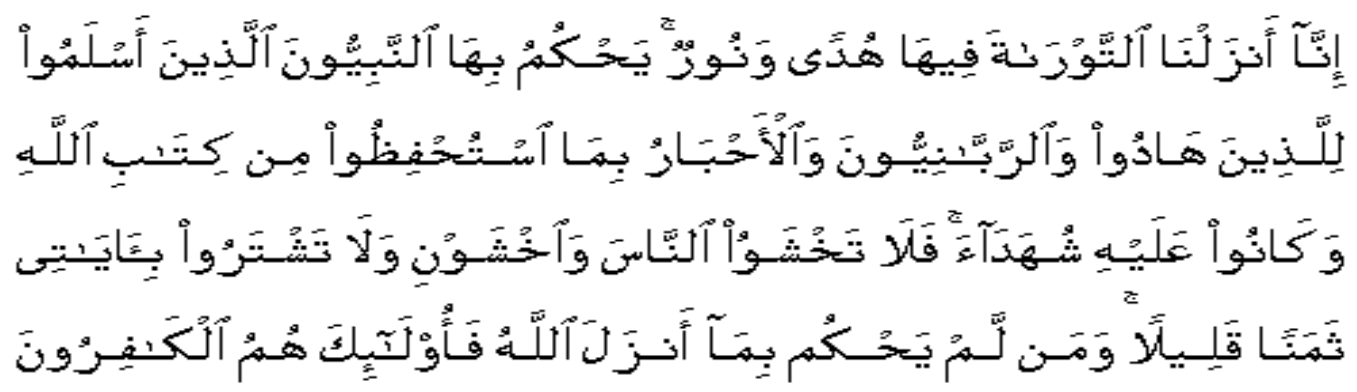

16 Sigit Sapto Nugroho, "Pengembangan Epistemologi Ilmu Hukum Berbasis Transendental," Jurnal Perspektif 21, no. 2 (2016): 98.

${ }^{17}$ Arief, Bunga Rampai Kebijakan Hukum Pidana: Perkembangan Penyusunan KUHP Baru.

${ }^{18}$ Pemerintah Republik Indonesia, "UU Nomor 22 Tahun 2009 Tentang Lalu Lintas Dan Angkutan Jalan" (Jakarta: Kementerian Pekerjaan Umum, 2009).

${ }_{19} \mathrm{M}$ Usman and M Ag, REKONSTRUKSI TEORI HUKUM ISLAM; Membaca Ulang Pemikiran Reaktualisasi Hukum Islam Munawir Sjadzali (LKIS PELANGI AKSARA, 2015).

${ }^{20}$ Departemen Kesehatan Republik Indonesia, "Undang-Undang No. 35 Tentang Narkotika Tahun 2009," Departemen Kesehatan Republik Indonesia, Jakarta, 2009.

${ }^{21}$ Pemerintah Republik Indonesia, "UU Nomor 31 Tahun 1999 Tentang Pemberantasan Tindak Pidana Korupsi” (1999). 
Artinya: Sesungguhya kami telah menurunkan Kitab Taurat di dalamnya (ada) petunjuk dan cahaya (yang menerangi, yang dengan kitab itu diputuskan perkara orang-orang Yahudi oleh nabi-nabi yang menyerah diri kepada Allah, oleh orang-orang alim mereka dan pendeta-pendeta mereka, disebabkan mereka diperintahkan memelihara kitab-kitab Allah dan mereka menjadi saksi terhadapnya. Karena itu janganlah kamu takut kepada manusia, tetapi takutlah kepada-Ku, dan janganlah kamu menukar ayatayatku dengan harga yang sedikit. Barangsiapa yang tidak memutuskan menurut apa yang diturunkan Allah, maka mereka itu adalah orang-orang yang kafir (Al-Qur'an: 5 (44)).

Secara tekstual ayat di atas memberikan pengertian bahwa segala keputusan hukum yang kita tetapkan berdasarkan kepada al-Qur'an (Ma Anzalallah). Dengan tawaran konsep reaktualisasi hukum Islam, konsep ma amazalallah di sini tidak berarti berpegang pada ketentuan makna harfiah-tekstual, akan tetapi kita harus melihat dan menangkap jiwa dan rukh al-Qur'an sebelum menolak realitas, sehingga apabila dalam kehidupan ini menemukan suatu aturan perundang-undangan yang dari segi semangat dan jiwanya relevan dengan al-Qur'an, maka aturan perundang-undangan tersebut dapat dikatakan sesuai dengan ajaran Islam, walaupun secara harfiah tidak disebutkan langsung oleh al-Qur'an atau bahkan bertentangan dengan makna harfiahnya. ${ }^{22}$

Menurut hemat penulis dengan berbagai pendapat tentang integrasi hukum Islam dan hukum pidana nasional memberikan optimisme bahwa hukum Islam dapat terinternalisasi dalam hukum sehingga tidak mustahil untuk diterapkan dan sebenarnya dapat diterima oleh semua kalangan. Penulis meyakini bahwa penerapan hukum Islam merupakan persoalan waktu karena membutuhkan waktu yang cukup panjang dan sumbangsi yang besar untuk lebih menginternalisasi dan mengaktualisasikan hukum Islam. Kita tidak boleh terburu-buru untuk mengklaim bahwa hukum yang sedang kita terapkan gagal karena pada kenyataanya berbagai produk hukum yang dihasilkan memberikan maslah meskipun masih terdapat hal-hal yang perlu untuk disempurnakan. Penulis beranggapan mengislamisasikan hukum nasional bukan solusi yang tepat dan kosep yang terlalu prematur jika dipaksakan untuk diterapkan ditengah gencatan modernitas yang berimbas pada tindak pidana yang mulai canggih. Sebaliknya kita patut mendorong upaya pemeritah untuk merampungkan hukum pidana nasional karena Negara sangat membutuhkan hukum pidana yang sesuai dengan karakter bangsa Indonesia selain itu upaya tersebut secara otomatis proses nasionalisasi hukum Islam dapat dilakukan karena pancasila telah menghendaki agama dijadikan sumber hukum nasional.

Sila pertama Ketuhanan yang Maha Esa merupakan suatu pertanda bahwa Negara Indonesia adalah negara yang bertuhanan dan implikasinya adalah tidak boleh ada paham ateis yang berkembang di Indonesia karena hal tersebut bertentangan dengan kultur masyarakat Indonesia yang religius. Sila pertama ini juga menunjukan bahwa hukum di Indonesia adalah hukum yang berketuhanan bukan hukum yang berladaskan pada paham liberal, komunis atau paham lain. Ukuran bertuhanan suatu hukum dapat dilihat sejauhmana agama dapat berkontribusi dalam pembentukan dan penerapan hukum nasional. Penerapan nilai-nilai hukum islam dalam hukum nasional dapat menggunakan hukum profetik dimana ajaran agama dijadikan sebagai landasan pembentukan hukum nasional.

Memadukan ilmu hukum pidana dan moral dalam konsep integrasi tidak saja membentengi watak hukum Indonesia yang religius bermoral. Akan tetapi, lebih dari itu konsep integrasi sebagai upaya menjawab kegagalan ilmu hukum menghadirkan keadilan dalam masyarakat. Termasuk pendekatan profetik sebagai koridor religiousitas ilmu hukum. ${ }^{23}$ Hukum pidana saat ini yang diberlakukan sebagai hukum warisan kolonial seharusnya telah mengalami pembaharuan karena konteks kehidupan di masa penjajahan sudah berbeda. Hukum warisan kolonial sudah ketinggalan zaman untuk tetap dipertahankan sehingga beberapa aturan pasal-pasal dalam KUHP memang seharusnya dirombak dan dibangun kembali sebagaimana teori hukum progresif yang menghendaki agar cara berhukum kita out of the box dan apabila hukum tersebut tidak lagi memberikan keadilan maka hukum tersebut harus di rombak dan dibangun kembali.

\footnotetext{
${ }^{22}$ Usman and Ag, REKONSTRUKSI TEORI HUKUM ISLAM; Membaca Ulang Pemikiran Reaktualisasi Hukum Islam Munawir Sjadzali.

${ }^{23}$ Slamet Haryadi, "Integrasi Ilmu Hukum Pidana Dan Moral: Suatu Telaah Kultur Tentang Tindak Pidana Suap Yang Melibatkan Aparat Penegak Hukum Di Wilayah Hukum Pengadilan Tindak Pidana Korupsi Karang Lampung" (Diponegoro University, 2016).
} 
Beberapa pasal dalam KUHP yang harus diperbaharui dan sementara disusun oleh pemerintah dalam RKUHP, yakni Pasal 284: ayat (1) Diancam dengan pidana penjara paling lama sembilan bulan, ayat (2) Penuntutan dilakukan hanya atas pengaduan suami/istri yang tercemar; dan bila bagi mereka berlaku pasal 27 Kitab Undang-undang Hukum Perdata, dalam tenggang waktu tigda bula diikuti dengan permintaan bercerai atau pisah meja dan ranjang karena alasan itu juga, Ayat (3) terhadap pengaduan ini tidak berlaku pasal 72,73, dan 75, Ayat (4) pengaduan dapat ditarik kembali selama pemeriksaan dalam sidang pengadilan belum dimulai, dan Ayat (5) Bila bagi suami-istri berlaku pasal 27 Kitab Undang-undang Hukum Perdata, pengaduan tidak diindahkan selama perkawinan belum diputuskan karena perceraian atau sebelum putusan yang menyatakan pisah meja dan ranjang menjadi tetap. ${ }^{24}$

Pasal 284 ayat (1) itu sendiri dirincikan lagi menjadi 4 bagian, yakni seseorang pria yang telah kawin yang melakukan mukah (verspel), padahal diketahuinya bahwa pasal 27 Kitab Undang-undang Hukum Perdata berlaku baginya; seorang wanita yang telah kawin yang melakukan mukah, padahal diketahuinya bahwa pasal 27 Kitab Undang-undang Hukum Perdata berlaku baginya; sesorang pria yang tutut serta melakukan perbuatan itu, padahal diketahuinya bahwa yang turut bersalah telah kawin; dan seorang wanita yang telah kawin yang turut serta melakukan perbuatan itu, padahal diketahuinya bahwa yang turut bersalah telah kawin dan pasal 27 Kitab Undang-undang Hukum Perdata berlaku baginya.

Menurut hukum pidana Islam, ancaman pidana disesuaikan dengan pelaku perzinahan. Jika pelaku zina itu muhsin atau telah menikah maka ancaman pidananya adalah rajam (stoning to death). Namun jika perzinahan itu dilakukan oleh orang yang belum menikah maka ancaman pidananya adalah cambuk atau didera sebanyak delapan puluh kali. Ketentuan yang mengatur mengenai persaksian tidak diatur secara khusus dalam delik perzinahan menurut KUHP. Maka system pembuktian delik perzinahan sama dengan sistem pembuktian delik-delik yang lain. ${ }^{25}$

Masyarakat Indonesia telah memahami bahwa segala bentuk hubungan badan yang dilakukan di luar pernikahan merupakan perzinahan dan hal tersebut wajib untuk dihukum. Namun dalam hukum positif persepsi masyrakat tidak selamanya benar sehingga dalam RKUHP perzinahan diperluas maknanya. Pasal 484 ayat 1 RUU KUHP mencakup perzinahan antara laki-laku dengan perempuan yang keduanya tak terikat perkawinan dan yang bisa jadi pengadu adalah pihak ketiga yang tercemar. ${ }^{26}$ RKUHP 2015 tindak pidana Zina diatur dalam pasal 484 angka (1) sampai (4). Adapun bunyi pasal tersebut disajikan pada Tabel 1.

Tabel 1. Deskripsi Pasal 484 angka (1) sampai (4)

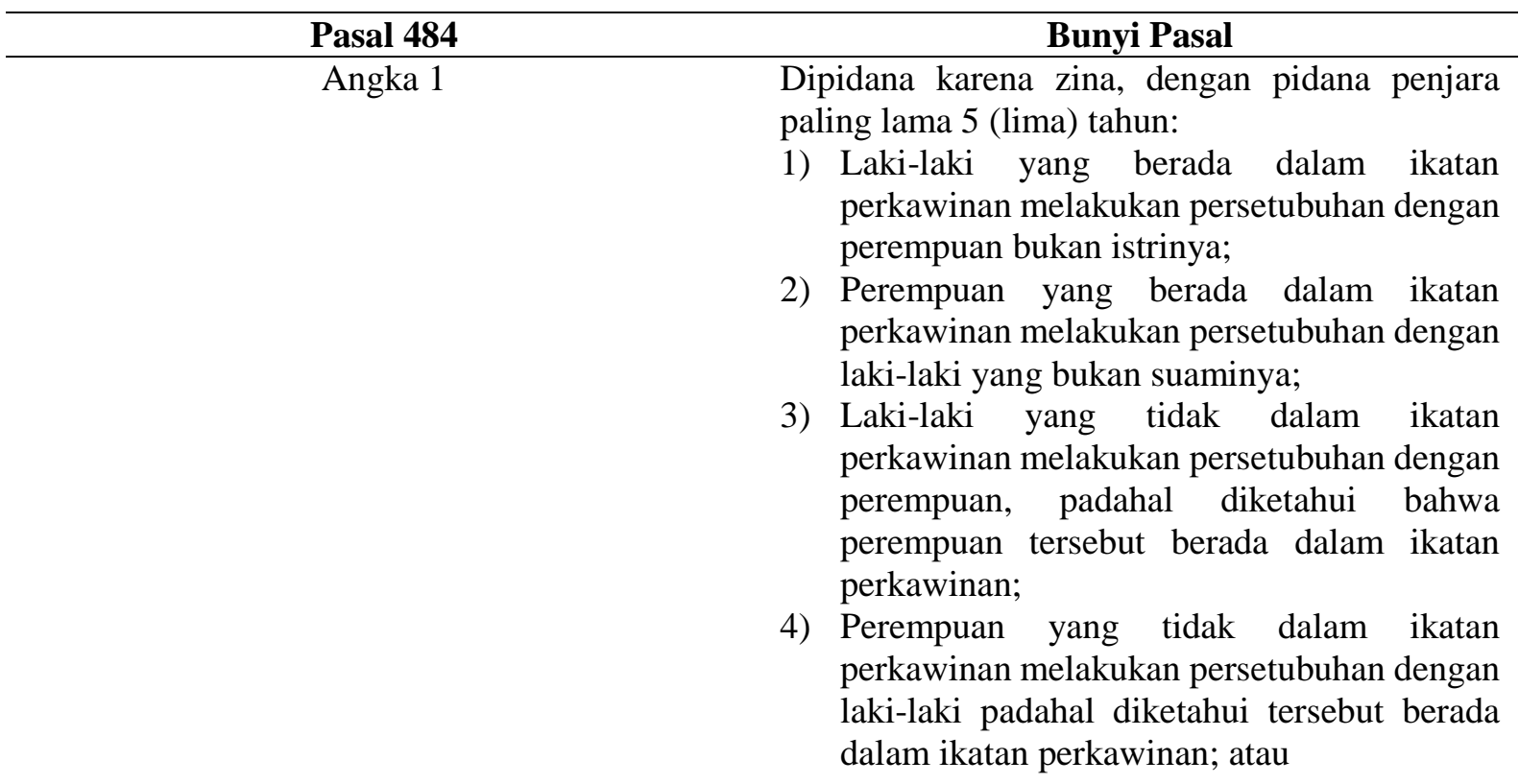

24 Eko Sugiyanto and Budhi Wisaksono Pujiyono, "Kebijakan Hukum Pidana Dalam Upaya Penanggulangan Tindak Pidana Perzinahan,” Diponegoro Law Journal 5, no. 3 (2016): 1-10.

${ }^{25}$ Sugiyanto and Pujiyono.

${ }^{26}$ Sugiyanto and Pujiyono. 


\begin{tabular}{cl}
\hline Pasal 484 & \multicolumn{1}{c}{ Bunyi Pasal } \\
\hline Angka 2 & 5) $\begin{array}{l}\text { Laki-laki dan perempuan yang masing- } \\
\text { masing tidak terikt dalam perkawinan yang } \\
\text { sah melakukan perstubuhan. }\end{array}$ \\
& $\begin{array}{l}\text { Tindak pidana sebagaimana dimaksud pada ayat } \\
\text { (1) tidak dilakukan penuntutan kecuali atas } \\
\text { pengaduan suami, istri atau pihak ketiga yang } \\
\text { tercemar. } \\
\text { Angka 3 } \\
\text { Terhadap pengaduan sebagaimana dimaksud } \\
\text { pada ayat (2) tidak berlaku ketentuan Pasal 26, } \\
\text { Pasal 27, dan Pasal 29. } \\
\text { Pengaduan dapat ditarik kembali selama } \\
\text { pemeriksaan di sidang pengadilan belum dimulai. }\end{array}$ \\
\hline
\end{tabular}

Menurut beberpa ahli hukum pidana Pasal 484 angka 1 hingga 4 merupakan rancangan yang mengoverkriminalisasi karena negara telah mengurus privat seseorang namun perzinahan merupakan perbuatan yang melanggar moral dan hukum agama sehingga hal tersebut harus ditanggulangi selain merumuskan aturan yang tegas dan keputusan hakim dengan memperhatikan hukum pidan materiil. Perumusan delik perzinahan yang dirumuskan oleh pemerintah merupakan sutau gagasan penerapan nilai hukum islam yang berbasiskan teori hukum profetik dimana perzinahan sebagai suatu perbuatan yang dilarang oleh Allah SWT yang tertuang dalam al-Qur'an kemudian diperluas maknanya dalam rumusan RKUHP bahwa yang termasuk zina bukan hanya yang terikat pernikahan secara bersama-sama melainkan segala bentuk hubungan badan di luar pernikahan termasuk zina dan harus dihukum.

Perumusan delik tersebut berasal dari perluasan asas legalitas dalam KUHP bahwa yang dapat dipidana bukan hanya perbuatan yang dilarang dalam aturan tertulis tetapi segala perbuatan yang bertentang dengan nilai-nilai yang hidup dalam masyarakat harus di hukum. Gagasan perluasan ini memberikan ruang kepada para ilmuwan hukum untuk mengkaji hukuman yang pantas bagi pelaku perzinahan jika dalam hukum Islam pelaku dihukum rajam dan hukum pidana warisan belanda dihukum penjara maka dalam pembaharuan hukum pidana masih tetap dipenjara dengan batasan dan ketentuan yang telah dibuat. Meskipun hukum yang dirancang adalah hukum penjara namun sebenarnya internalisasi nilai hukum Islam dengan dipidana penjara telah mengandung nilai dan spirit agama islam dengan hukum rajam meskipun tidak disebutkan secara eksplisit hukum rajamnya dalam KUHP maupun RKUHP.

\section{SIMPULAN DAN SARAN}

\section{Simpulan}

Indonesia sebagai Negara yang beKeTuhanan Yang Maha Esa berimplikasi kepada pengakuan terhadap agama-agama dan keyakinan yang berada di Indonesia. Hukum Islam sebagai salah satu hukum yang diakui dan diberlakukan di Indonesia memuat nilai-nilai Universal yang sangat relevan terhadap perkembangan kehidupan masyarakat di Indonesia. Mengintegrasikan nilai-nilai hukum Islam dalam pembahruan hukum pidana (RKUHP) terhadap perzinahan merupakan hal yang sangat tepat karena tujuan hukum Islam yakni menjaga akal, jiwa, keturunan dan harta dapat diaktualisasikan dengan memperbaharui aturan-aturan tentang perzinahan yang tidak hanya terhadap pasangan yang sudah menikah melainkan terhadap pasangan yang belum terikat pada pernikahan. Hukum Islam sebagai salah satu sumber hukum pidana nasional telah dilegitimasi oleh Pancasila dan UUD 1945 sehingga kekuatan hukumnya dapat mengikat dalam penerpan hukum terhadap 3 struktur hukum yakni substansi, kulture dan structure.

\section{Saran}

Penulis berharap integrasi hukum Islam dalam pembahruan hukum pidana Indonesia (RKUHP) tidak terhenti pada konsep semata namun dapat melakukan kajian mendalam terhadap peran hukum agama dalam pembentukan hukum nasional selain itu ahli hukum pidan Islam dapat berkontribusi langsung dalam penyusunan RKUHP agar persfektifnya terhadap hukum nasional dapat seimbang. Membenturkan hukum pidana Islam dengan rancangan hukum bukan hal yang relevan untuk dilakukan 
karena penyusnan hukum pidana nasional (RKUHP) tidak terlepas dari kajian terhadap hukum Pidana Islam.

\section{DAFTAR PUSTAKA}

Abdul, Wahid. Menggugat Idealisme KUHP. Bandung: Tarsito, 1993.

Ali, Zainuddin. Metode Penelitian Hukum. Jakarta: Sinar Grafika, 2009.

Arief, Barda Nawawi. Bunga Rampai Kebijakan Hukum Pidana: Perkembangan Penyusunan KUHP Baru. Jakarta: Kencana Prandamedia Group, 2010.

Bo'a, Fais Yonas. "Pancasila Sebagai Sumber Hukum Dalam Sistem Hukum Nasional." Jurnal Konstitusi 15, no. 1 (2018): 21-49.

Haryadi, Slamet. "Integrasi Ilmu Hukum Pidana Dan Moral: Suatu Telaah Kultur Tentang Tindak Pidana Suap Yang Melibatkan Aparat Penegak Hukum Di Wilayah Hukum Pengadilan Tindak Pidana Korupsi Karang Lampung.” Diponegoro University, 2016.

Indonesia, Departemen Kesehatan Republik. "Undang-Undang No. 35 Tentang Narkotika Tahun 2009." Departemen Kesehatan Republik Indonesia, Jakarta, 2009.

Indonesia, Pemerintah Republik. "Undang-Undang Dasar Negara Republik Indonesia 1945.” Lembaran Negara RI Tahun1959 Nomor 75 (1959).

_. "UU Nomor 22 Tahun 2009 Tentang Lalu Lintas Dan Angkutan Jalan.” Jakarta: Kementerian Pekerjaan Umum, 2009.

—. UU Nomor 31 Tahun 1999 tentang pemberantasan tindak pidana korupsi (1999).

—. UU Nomor 7 Tahun 1989 tentang Peradilan Agama (1989).

Mamudji, Sri, and Soerjono Soekanto. Penelitian Hukum Normatif. Jakarta: PT. Raja Grafindo, 2006.

Maula, Bani Syarif. Sosiologi Hukum Islam Di Indonesia: Studi Tentang Realitas Hukum Islam Dalam Konfigurasi Sosial Dan Politik. Aditya Media Publishing, 2010.

Nugroho, Sigit Sapto. "Pengembangan Epistemologi Ilmu Hukum Berbasis Transendental." Jurnal Perspektif 21, no. 2 (2016): 98.

Prasetyo, Teguh. Politik Hukum Pidana: Kajian Kebijakan Kriminalisasi Dan Dekriminalisasi. Yogyakarta: Pustaka Pelajar, 2012.

Soerjono, Soekanto. Pengantar Penelitian Hukum. Jakarta: Universitas Indonesia, 1986.

Sugiyanto, Eko, and Budhi Wisaksono Pujiyono. "Kebijakan Hukum Pidana Dalam Upaya Penanggulangan Tindak Pidana Perzinahan." Diponegoro Law Journal 5, no. 3 (2016): 1-10.

Syah, Ismail Muhammad. Filsafat Hukum Islam. Jakarta: Bumi Aksara, 1999.

Syamsudin, M. Ilmu Hukum Profetik: Gagasan Awal, Landasan Kefilsafatan, Dan Kemungkinan Pengembangannya Di Era Postmodern. Pusat Studi Hukum (PSH) FH UII kerja sama dengan FH UII Press, 2013.

Umar, Nasaruddin. "Urgensi Transformasi Hukum Islam Dalam Pemajuan Hak Asasi Manusia Di Indonesia." HUNAFA: Jurnal Studia Islamika 12, no. 2 (2015): 231-52.

Usman, M, and M Ag. REKONSTRUKSI TEORI HUKUM ISLAM; Membaca Ulang Pemikiran Reaktualisasi Hukum Islam Munawir Sjadzali. LKIS PELANGI AKSARA, 2015.

Wibowo, Sugeng. "Integrasi Epistimologi Hukum Transendental Sebagai Paradigma Hukum Indonesia." Legal Standing: Jurnal Ilmu Hukum 1, no. 1 (2017): 61-88. 